\title{
Iptek bagi Masyarakat Taman Kanak-Kanak di Desa Kalitirto Kecamatan Berbah
}

\author{
Rizqi Sukma Kharisma ${ }^{1}$, Istiningsih ${ }^{2}$ \\ ${ }^{1,2}$ Universitas Amikom Yogyakarta, Jl. Ringroad Utara, Condong Catur, Depok, Sleman, \\ Yogyakarta, \\ ${ }^{1}$ sukma@amikom.ac.id, ${ }^{2}$ istiningsih@amikom.ac.id
}

\begin{abstract}
Berbah is sub-districts of Sleman, Yogyakarta, which has 21 kindergarten school as a formal education for children. Two of kindergartens has been obtained accreditation B, are Aisiyah Bustanul Atfhal $(A B A)$ Berbah and Lestari kindergartens. The accreditation proof that the kindergarten is a potential as sample for kindergarten. Unfortunately, that kindergarten don't have technology for school management and learning process. Scholl management use manually process for creating a letter, and they rent a computer for creating digital document. They have a problem to inform the parent of student and third parties relation. The learning process media still use a chalk and manual simulation.Computer-based process is the solution to solve the problem above. Learning process is better to convert to computer-based and simulation is convert to multimedia-based. The new method need some computer with the multimedia specification; such as laptop, speaker and projector for each kindergartens. The outcome of these activities are to increase the understanding for teachers and employees of computer-based school management. The additional output are the application of learning media that can be used the teachers and kindergarten students to support the learning management and simulation process. Finally, the general result of these activities is to improve the quality education in both potential kindergarten by using information technology.
\end{abstract}

Keywords: kindergarten school, management, media learning

\begin{abstract}
ABSTRAK
Berbah adalah kecamatan Sleman, Yogyakarta, yang memiliki 21 sekolah taman kanak-kanak sebagai pendidikan formal untuk anak-anak. Dua taman kanak-kanak telah mendapatkan akreditasi B, adalah taman kanak-kanak Aisiyah Bustanul Atfhal (ABA) Berbah dan Lestari. Bukti akreditasi bahwa taman kanak-kanak berpotensi dijadikan sampel untuk taman kanak-kanak. Sayangnya, taman kanak-kanak itu tidak memiliki teknologi manajemen sekolah dan proses belajar. Manajemen sekolah menggunakan proses manual untuk membuat surat, dan mereka menyewa komputer untuk membuat dokumen digital. Mereka memiliki masalah untuk menginformasikan kepada orang tua hubungan siswa dan pihak ketiga. Proses pembelajaran masih menggunakan kapur dan simulasi manual. Proses berbasis komputer adalah solusi untuk mengatasi masalah di atas. Proses belajar lebih baik untuk berkonversi ke komputer berbasis simulasi dan konversinya menjadi berbasis multimedia. Metode baru membutuhkan beberapa komputer dengan spesifikasi multimedia; Seperti laptop, speaker dan proyektor untuk setiap taman kanak-kanak. Hasil dari kegiatan ini adalah untuk meningkatkan pemahaman guru dan karyawan manajemen sekolah berbasis komputer. Output tambahannya adalah penerapan media pembelajaran yang bisa digunakan para guru dan siswa taman kanak-kanak untuk menunjang proses pembelajaran manajemen dan simulasi. Akhirnya, hasil umum dari kegiatan ini adalah untuk meningkatkan kualitas pendidikan di kedua taman kanak-kanak dengan menggunakan teknologi informasi.
\end{abstract}

Kata kunci: taman kanak-kanak, manajemen, media pembelajaran

\section{PENDAHULUAN}

TK Lestari Berbah merupakan sebuah TK yang beralamat di Jl. Berbah Prambanan, Dusun Sumber Kidul, Kelurahan Kalitrirto, Kecamatan Berbah, Sleman. TK ini memiliki potensi untuk berkembang dengan didukung dengan penilaian akreditasi yang telah didapat yaitu akreditasi B. Jumlah siswa pada TK Lestari Berbah relatif stabil yang disajikan pada Tabel 1 berikut : 
Tabel 1. Jumlah Siswa TK Lestari Berbah

\begin{tabular}{ccrr}
\hline Tahun & \multicolumn{2}{c}{ Kelas } & \multirow{2}{*}{ Jumlah } \\
\cline { 2 - 4 } Ajaran & A & \multicolumn{1}{c}{ B } & \\
\hline $2010 / 2011$ & 18 & 15 & 33 \\
\hline $2011 / 2012$ & 18 & 14 & 32 \\
\hline $2012 / 2013$ & 14 & 14 & 28 \\
\hline $2013 / 2014$ & 15 & 15 & 30 \\
\hline $2014 / 2015$ & 17 & 15 & 32 \\
\hline
\end{tabular}

Jumlah pengajar dan staff administrasi tidak proporsional, bahkan guru kelas juga merangkap sebagai staff administrasi dan kebersihan. Hanya terapat 4 orang personil dalam TK Lestari berbah. yang disajikan pada Tabel 2:

Tabel 2. Daftar Guru dan Staff TK Lestari Berbah

\begin{tabular}{llll}
\hline No & \multicolumn{1}{c}{ Nama } & \multicolumn{1}{c}{ Jabatan } & \multicolumn{1}{c}{ NUPTK } \\
\hline 1 & Dwi Ariyani, S.Pd.Aud & Kepala Sekolah & 4548754656300020 \\
\hline 2 & Isti Konaah, S.Pd & Guru Kelas Kelompok B & 8544741643300020 \\
\hline 3 & Siti Fatimah,S.Pd.Aud & Guru Kelas Kelompok A & 0542749651300032 \\
\hline 4 & Saminah & Tenaga Kebersihan & 8453749652210030 \\
\hline
\end{tabular}

TK Aisiyah Bustanul Atfhal (ABA) Berbah merupakan TK yang berada di Jl. Berbah Utara, Dusun Berbah, Kelurahan Kalitirto, Kecamatan Berbah, Sleman. TK ini memiliki akreditasi B dengan jumlah siswa yang relatif stabil dari tahun ke tahun yang disajikan pada Tabel 3 berikut:

Tabel 3. Jumlah Siswa TK Aisiyah Bustanul Atfhal (ABA)

\begin{tabular}{|c|c|c|c|}
\hline \multirow{2}{*}{$\begin{array}{c}\text { Tahun } \\
\text { Ajaran }\end{array}$} & \multicolumn{2}{|c|}{ Kelas } & \multirow{2}{*}{ Jumlah } \\
\hline & $\mathbf{A}$ & B & \\
\hline $2010 / 2011$ & 17 & 16 & 43 \\
\hline $2011 / 2012$ & 17 & 23 & 40 \\
\hline $2012 / 2013$ & 24 & 24 & 48 \\
\hline $2013 / 2014$ & 20 & 24 & 44 \\
\hline $2014 / 2015$ & 21 & 24 & 45 \\
\hline
\end{tabular}

Jumlah personil yang berada di TK Aisiyah Bustanul Atfhal (ABA) Berbah sebanyak 4 personil yang merangkap sebagai guru dan petugas administrasi. Personil TK Aisiyah Bustanul Atfhal (ABA) Berbah disajikan pada Tabel 4 berikut:

Tabel 4. Daftar Guru dan Staff TK Aisiyah Bustanul Atfhal (ABA) Berbah

\begin{tabular}{llll}
\hline No & \multicolumn{1}{c}{ Nama } & \multicolumn{1}{c}{ Jabatan } & \multicolumn{1}{c}{ NUPTK } \\
\hline 1 & Sumiyati, S.Pd. AUD & Kepala Sekolah & 3261755657300020 \\
\hline 2 & Rubiyanti, S.Pd & Guru Kelas Kelompok B & 8156740641300013 \\
\hline 3 & Suwartinah, S.Pd.AUD & Guru Kelas Kelompok A & 6640743647300002 \\
\hline 4 & Nur Khasah & Guru Kelas Kelompok A & - \\
\hline
\end{tabular}

Namun kegiatan belajar mengajar di TK Lestari Berbah dan TK Aisiyah Bustanul Atfhal (ABA) Berbah dilakukan dengan menggunakan alat peraga manual. Kegitan belajar mengajar belum menggunakan sarana teknologi informasi dan komputer (TIK). Jika ingin menggunakan media-media belajar teknologi informasi dan komputer (TIK), kedua TK menyewa pihak ketiga 
sehingga membutuhkan biaya tambahan dan tidak dapat digunakan sewaktu-waktu. Begitu juga dengan kegiatan manajemen dan administrasi sekolah dilakukan secara manual menggunakan tulis tangan. Jika pun diketik menggunakan komputer menggunakan komputer rental atau dengan komputer pribadi kepala sekolah. Hal ini menyulitkan bagi guru dan staff dalam membuat dokumen-dokumen yang berhubungan dengan manajemen sekolah. Selain itu tidak semua guru memiliki kemampuan dalam penggunaan sarana teknologi informasi dan komputer (TIK). Tidak adanya koneksi Internet, sehingga pengaksesan informasi-informasi terkini dari Internet mengalami kesulitan.

Setelah melakukan observasi dan wawancara dengan calon mitra yaitu TK Lestari Berbah dan TK Aisiyah Bustanul Atfhal (ABA) Berbah serta pengamatan langsung di lapangan didapatkan beberapa permasalahan. Permasalahan-permasalahan tersebut kemudian didiskusikan dengan calon mitra dan mendapatkan kesepakatan prioritas permasalahan yang disajikan pada tabel 5 dan tabel 6 .

Tabel 5 Daftar Masalah dan Prioritas TK Lestari

\begin{tabular}{|c|c|c|}
\hline No & Permasalahan & No Prioritas \\
\hline 1 & $\begin{array}{l}\text { Kegiatan manajemen dan administrasi sekolah dilakukan secara } \\
\text { manual menggunakan tulis tangan. Pengetikan dokumen-dokumen } \\
\text { tertentu menggunakan rental komputer. Sehingga pembuatan dan } \\
\text { pencarian data mengalami kesulitan }\end{array}$ & Prioritas 1 \\
\hline 2 & $\begin{array}{l}\text { Kegiatan belajar mengajar diakukan secara konvensional } \\
\text { menggunakan alat peraga manual, sering guru-guru mengalami } \\
\text { kesulitan untuk menampilkan materi-materi tertentu kepada siswa }\end{array}$ & Prioritas 4 \\
\hline 3 & $\begin{array}{l}\text { Tidak adanya koneksi Internet, sehingga pengaksesan informasi- } \\
\text { informasi terkini dari Internet mengalami kesulitan. }\end{array}$ & Prioritas 3 \\
\hline 4 & $\begin{array}{l}\text { Pemahaman pengunaan teknologi informasi dan komputer dalam } \\
\text { manajemen sekolah yang rendah bagi Guru dan Staff mitra }\end{array}$ & Prioritas 2 \\
\hline 5 & $\begin{array}{l}\text { Kurangnya tenaga administrasi, sehingga guru dan kepala sekolah } \\
\text { merangkap sebagai tenaga administrasi }\end{array}$ & Prioritas 8 \\
\hline 6 & $\begin{array}{l}\text { Fasilitas sanitasi kurang memadahi, sumber air bersumber dari SD } \\
\text { yang berada di samping gedung mitra }\end{array}$ & Prioritas 5 \\
\hline 7 & $\begin{array}{l}\text { Tempat parkir yang belum memdahi, sehingga guru maupun orang } \\
\text { tua siswa mengalami kesulitan saat mengantar dan menjemput anak- } \\
\text { anaknya yang bersekolah di mitra }\end{array}$ & Prioritas 6 \\
\hline 8 & $\begin{array}{l}\text { Ruang kelas belum sesuai standart, daya tampung siswa dan luas } \\
\text { ruangan untuk kegiatan belajar mengajar tidak ideal. Suasana } \\
\text { kegiatan belajar mengajar terasa panas }\end{array}$ & Prioritas 7 \\
\hline \multicolumn{3}{|c|}{ Tabel 6. Daftar Masalah dan Prioritas TK Aisiyah Bustanul Atfhal (ABA) Berbah } \\
\hline No & Permasalahan & No Prioritas \\
\hline 1 & $\begin{array}{l}\text { Kegiatan manajemen dan administrasi sekolah dilakukan secara } \\
\text { manual menggunakan tulis tangan. Pengetikan dokumen-dokumen } \\
\text { tertentu menggunakan rental komputer. Sehingga pembuatan dan } \\
\text { pencarian data mengalami kesulitan }\end{array}$ & Prioritas 1 \\
\hline 2 & $\begin{array}{l}\text { Kegiatan belajar mengajar diakukan secara konvensional } \\
\text { menggunakan alat peraga manual, sering guru-guru mengalami } \\
\text { kesulitan untuk menampilkan materi-materi tertentu kepada siswa }\end{array}$ & Prioritas 4 \\
\hline 3 & $\begin{array}{l}\text { Tidak adanya koneksi Internet, sehingga pengaksesan informasi- } \\
\text { informasi terkini dari Internet mengalami kesulitan. }\end{array}$ & Prioritas 3 \\
\hline 4 & $\begin{array}{l}\text { Pemahaman pengunaan teknologi informasi dan komputer dalam } \\
\text { manajemen sekolah yang rendah bagi Guru dan Staff mitra }\end{array}$ & Prioritas 2 \\
\hline 5 & $\begin{array}{l}\text { Kurangnya tenaga administrasi, sehingga guru dan kepala sekolah } \\
\text { merangkap sebagai tenaga administrasi }\end{array}$ & Prioritas 5 \\
\hline 6 & Tempat parkir yang belum memdahi, sehingga guru maupun orang & Prioritas 6 \\
\hline
\end{tabular}


tua siswa mengalami kesulitan saat mengantar dan menjemput anakanaknya yang bersekolah di mitra

\section{METODE PELAKSANAAN}

Permasalahan-permasalahan yang terdapat pada tabel 1.5 dan tabel 1.6 kemudian dietapkan empat prioritas utama yang diselesaikan dengan solusi dari masalah-masalah tersebut :

1. Kegiatan manajemen dan administrasi sekolah dilakukan secara manual menggunakan tulis tangan. Pengetikan dokumen-dokumen tertentu menggunakan rental komputer. Sehingga pembuatan dan pencarian data mengalami kesulitan. Dilakukan kegiatan :

a. Penyediaan perangkat teknologi informasi dan komputer (TIK) sebagai penunjang kegiatan manajemen dan administrasi sekolah. Meliputi komputer / laptop dan printer

2. Pemahaman pengunaan teknologi informasi dan komputer (TIK) dalam manajemen sekolah yang rendah bagi Guru dan Staff mitra. Dilakukan kegiatan :

a. Pelatihan pengunaan teknologi informasi dan komputer (TIK) dalam manajemen sekolah. Guru dan staff mitra melakukan pelatihan komputer dan internet sehingga mampu menggunakanya.

3. Tidak adanya koneksi Internet, sehingga pengaksesan informasi-informasi terkini dari Internet mengalami kesulitan.

a. Penyediaan perangkat pendukung untuk koneksi internet dengan menggunakan modem $4 \mathrm{G}$

4. Kegiatan belajar mengajar diakukan secara konvensional menggunakan alat peraga manual, sering guru-guru mengalami kesulitan untuk menampilkan materi-materi tertentu kepada siswa

a. Pembuatan media pembelajaran multimedia

b. Pelatihan penggunaan media pembelajaran multimedia

c. Penyediaan perangkat teknologi informasi dan komputer (TIK) sebagai penunjang pembelajaran multimedia, meliputi screen proyektor, proyektor dan speaker aktif.

\section{HASIL DAN PEMBAHASAN}

Penyediaan perangkat teknologi informasi dan komputer (TIK) sebagai penunjang kegiatan manajemen dan administrasi sekolah untuk menyelesaikan masalah di mana kegiatan manajemen dan administrasi sekolah dilakukan secara manual menggunakan tulis tangan. Pengetikan dokumen-dokumen tertentu menggunakan rental komputer. Sehingga pembuatan dan pencarian data mengalami kesulitan. Perangkat teknologi informasi dan komputer (TIK) yang di sediakan berupa :

1. Laptop Lenovo IdeaPad 110-141IBR

2. Canon Pixma iP2770

Penyediaan perangkat pendukung untuk koneksi internet menyelesaikan masalah di mana Tidak adanya koneksi Internet, sehingga pengaksesan informasi-informasi terkini dari Internet mengalami kesulitan. Penyediaan perangkat pendukung untuk koneksi internet berupa :

1. Modem Andromax M2Y 4G

Penyediaan perangkat teknologi informasi dan komputer (TIK) sebagai penunjang pembelajaran multimedia, bertujuan untuk sebagai penunjang media pembelajaran yang digunakan untuk menyelasikan masalah kegiatan belajar mengajar diakukan secara konvensional menggunakan alat peraga manual, sering guru-guru mengalami kesulitan untuk menampilkan materi-materi tertentu kepada siswa. Perangkat ini berupa :

1. Proyektor Infocus IN220

2. Speaker Genius SP-U120

3. Screen Proyektor 


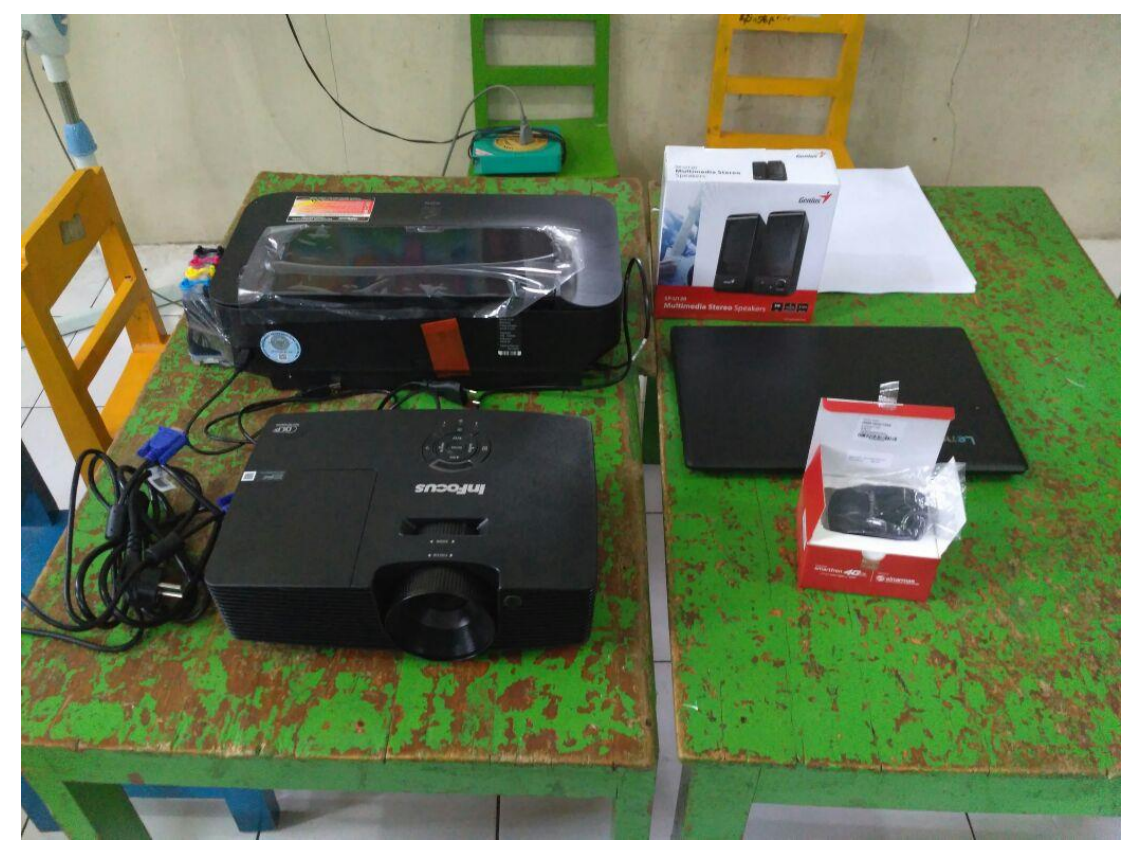

Gambar 1 Perangkat Laptop, Printer, Proyektor, Speaker dan Modem Internet

Pembuatan media pembelajaran multimedia ini bertujuan untuk sebagai penunjang media pembelajaran yang digunakan untuk menyelasikan masalah kegiatan belajar mengajar diakukan secara konvensional menggunakan alat peraga manual, sering guru-guru mengalami kesulitan untuk menampilkan materi-materi tertentu kepada siswa. Dari pembuatan aplikasi media pembelajaran ini dihasilkan dua buah media pembelajaran yaitu :

1. Mengenal Huruf Hijai'iyah

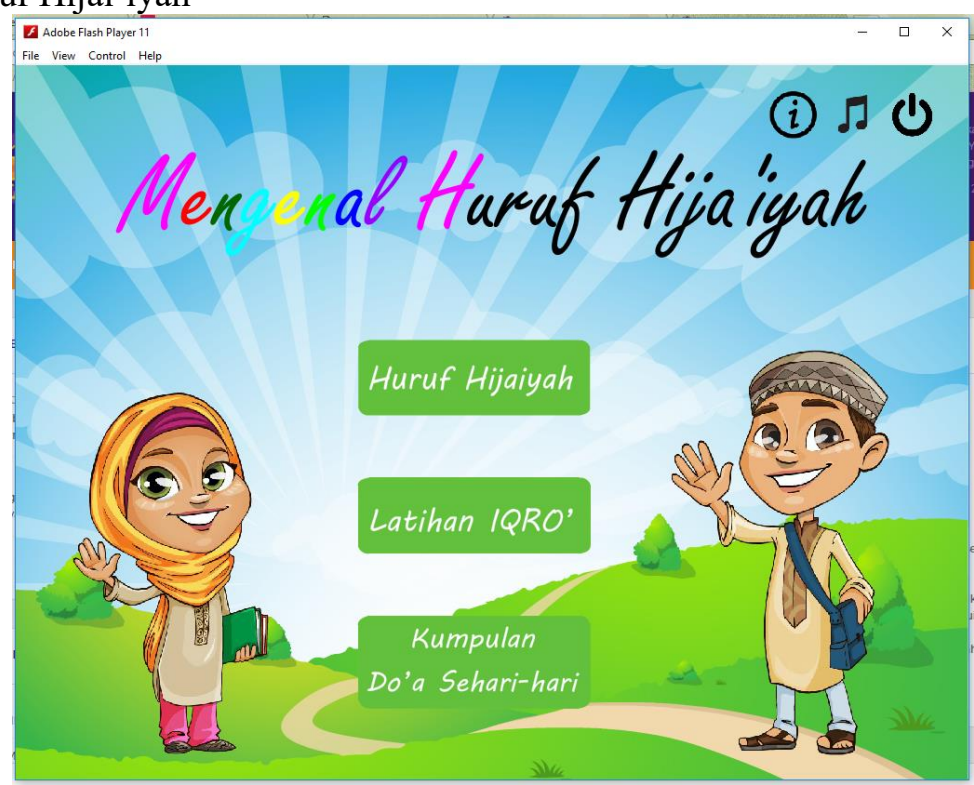

Gambar 2 Aplikasi Pembelajaran Multimedia Mengenl Huruf Hija'iyah

Pada aplikasi ini memiliki fitur :

a. Huruf Hija'iyah, pada menu ini berisikan urutan huruf hija'iyah beserta cara pengucapannya dalam bentuk gambar dan suara.

b. Latihan Iqro', pada menu ini berisikan gabungan huruf hija'iyah yang memiliki kharokat beserta cara pengucapannya dalam bentuk gambar dan suara.

c. Kumpulan Do'a Sehari-Hari, pada menu ini berisikan doa-doa sehari yang disajikan dalam bentuk suara dan huruf arab serta terjemahan. 
2. Belajar Mengenal

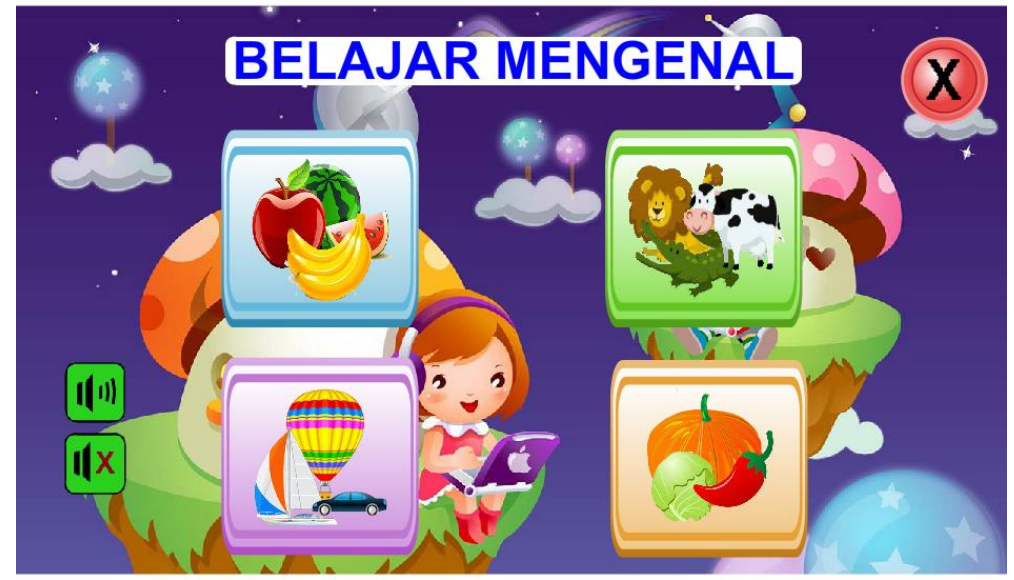

Gambar 3 Aplikasi Media Pembelajaran Multimedia Belajar Mengenal

Pada aplikasi ini memiliki fitur :

a. Mengenal Buah-Buahan, pada menu ini disajikan gambar buah beserta nama buah yang dilengkapi dengan suara.

b. Mengenal Hewan, pada menu ini disajikan gambar hewan beserta nama hewan yang dilengkapi dengan suara.

c. Mengenal Alat Transportasi, pada menu ini disajikan gambar alat transportasi beserta nama alat transportasi yang dilengkapi dengan suara.

d. Mengenal Sayuran, pada menu ini disajikan gambar sayuran beserta nama sayuran yang dilengkapi dengan suara.

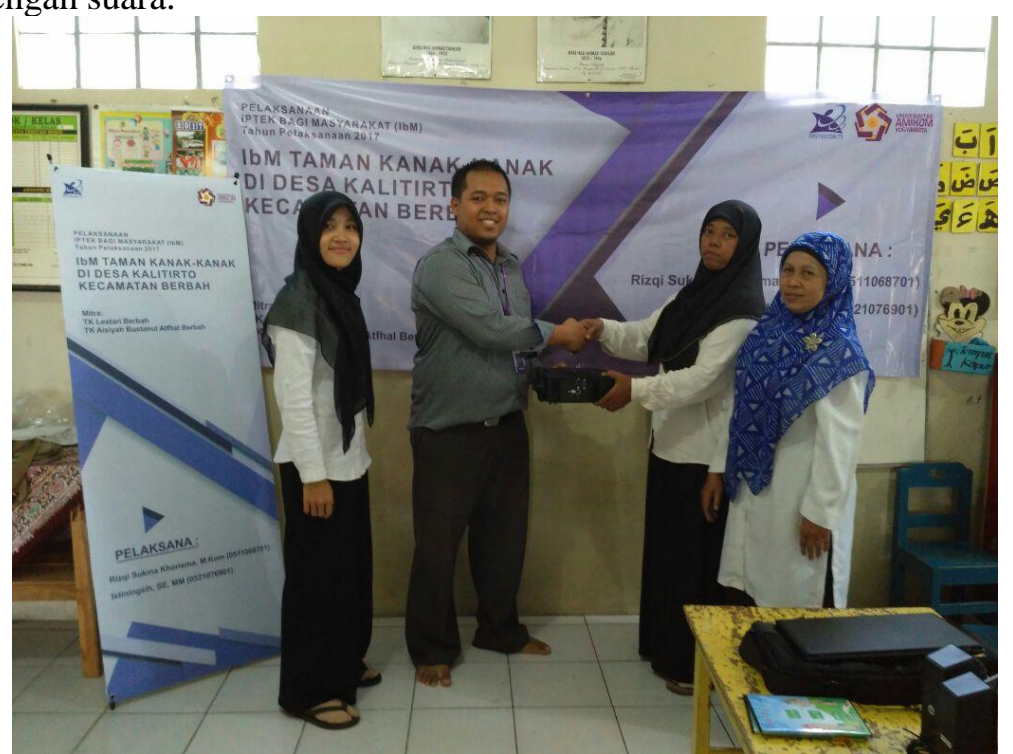

Gambar 4 Penyerahan Secara Simbolis Kepada TK Aisiyah Bustanul Atfhal (ABA) Berbah 


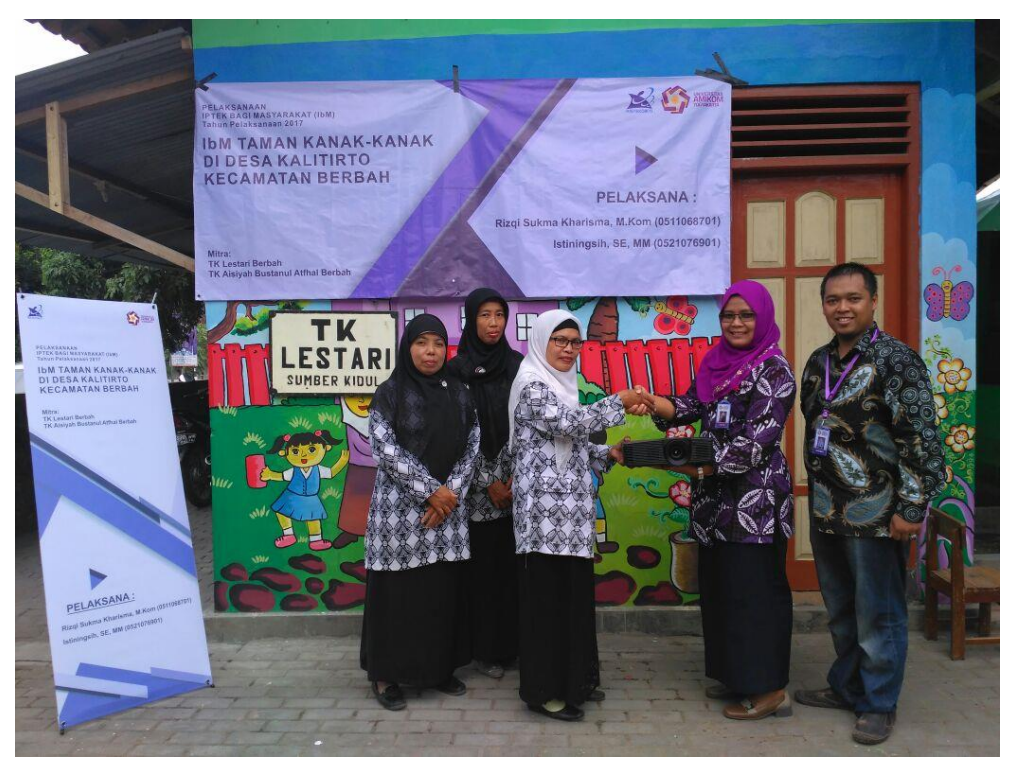

Gambar 5 Penyerahan Secara Simbolis Kepada TK Lestari Berbah

Pelatihan yang dilaksanakan pada TK Aisiyah Bustanul Atfhal (ABA) Berbah dan TK Lestari Berbah dilaksanakan meliputi :

1. Pelatihan pengunaan teknologi informasi dan komputer (TIK) dalam manajemen sekolah. Pada pelatihan ini para guru TK dilatih agar dapat menggunakan teknologi informasi dan komputer (TIK) secara umum dan untuk keperluan manajemen sekolah. Guru diajarkan bagaimana menggunakan perangkat teknologi informasi dan komputer (TIK) meliputi penggunaan komputer secara umum, cara koneksi internet, penggunaan printer dan penggunaan Microsoft Office sebagai media pengelolaan manajemen sekolah.

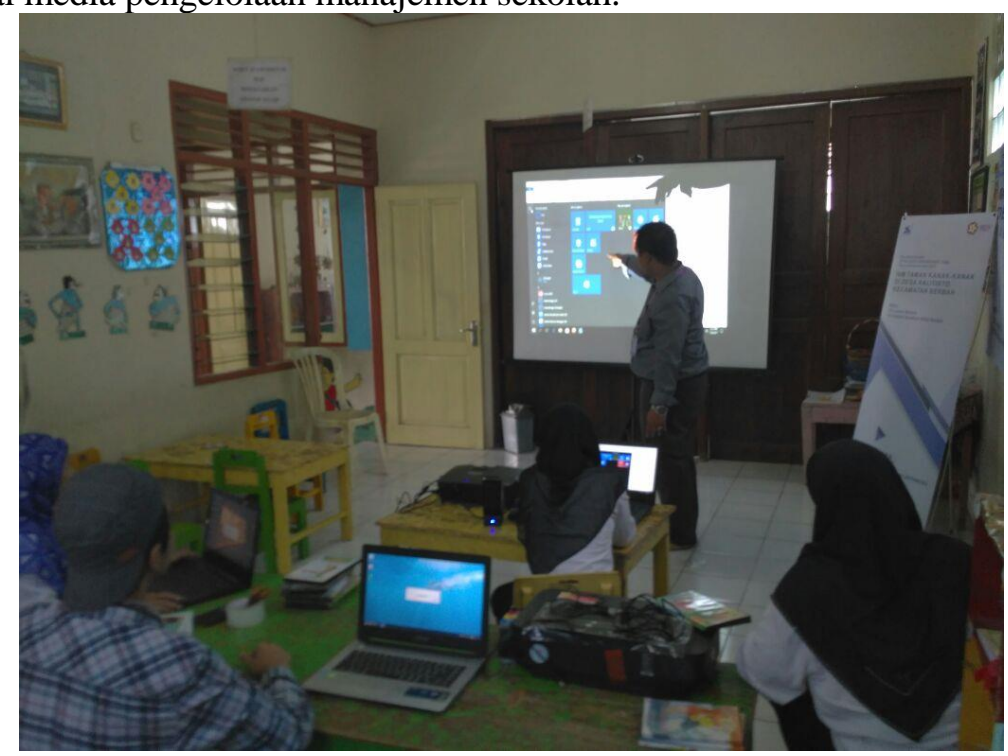

Gambar 6 Pelatihan pengunaan teknologi informasi dan komputer (TIK) dalam manajemen sekolah di TK Aisiyah Bustanul Atfhal (ABA) Berbah 


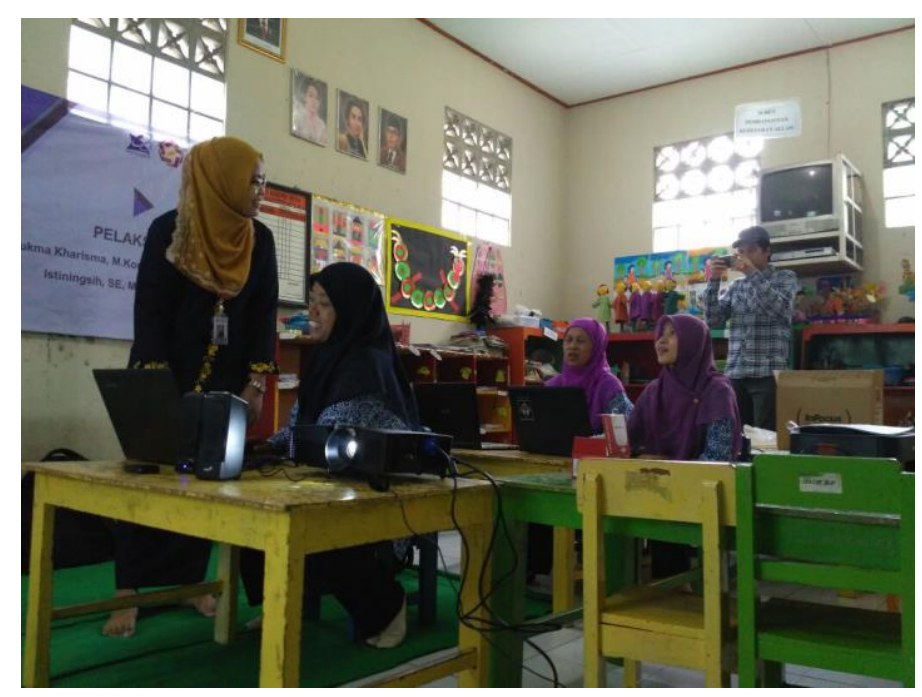

Gambar 7 Pelatihan pengunaan teknologi informasi dan komputer (TIK) dalam manajemen sekolah di TK Aisiyah Bustanul Atfhal (ABA) Berbah

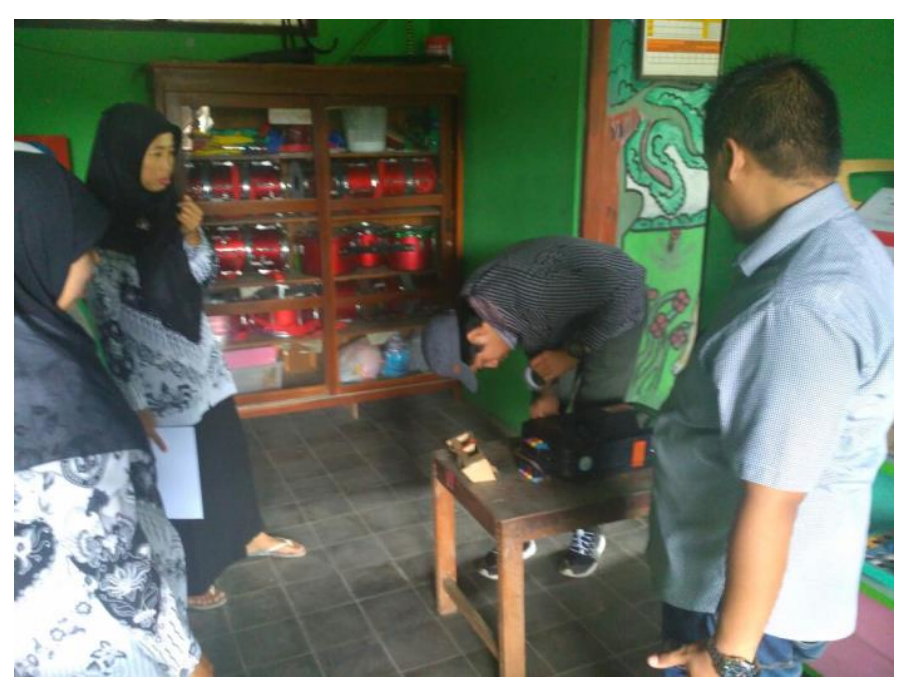

Gambar 8 Pelatihan pengunaan teknologi informasi dan komputer (TIK) dalam manajemen sekolah di TK Lestari Berbah

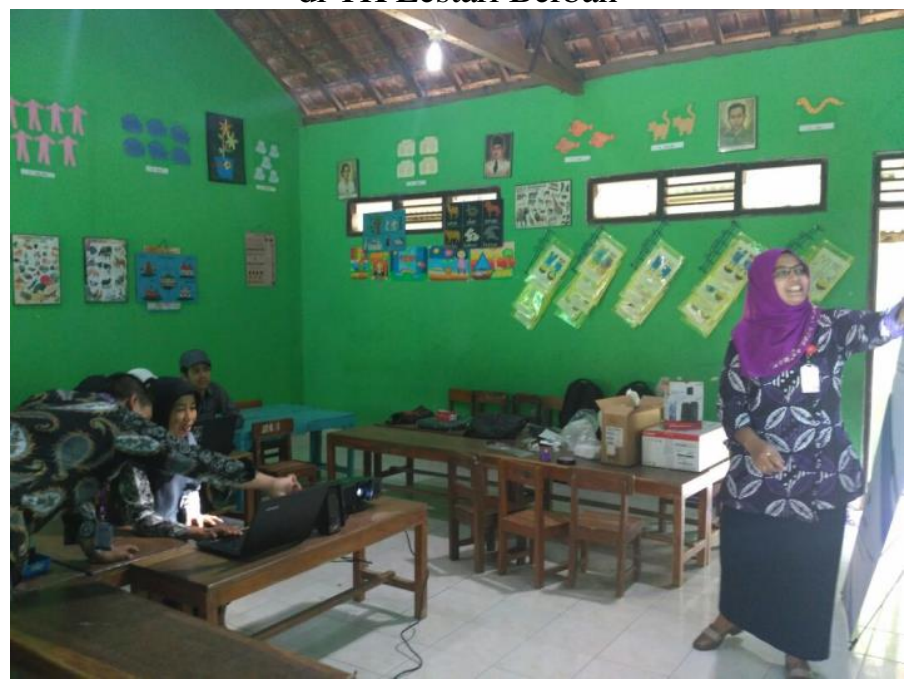

Gambar 9 Pelatihan pengunaan teknologi informasi dan komputer (TIK) dalam manajemen sekolah di TK Lestari Berbah 
2. Pelatihan penggunaan media pembelajaran multimedia. Pada pelatihan ini, guru-guru TK diberikan pelatihan dalam penggunaan media pembelajaran multimedia beserta penggunaan alat pendukungnya. Guru diajarkan bagaimana menggunakan screen proyektor, instalasi dan penggunaan proyektor, instalasi speaker dan penggunaan media pembelajaran multimedia. Guru juga diberikan pendampingan saat menyampaikan kepada siswa-siswinya.

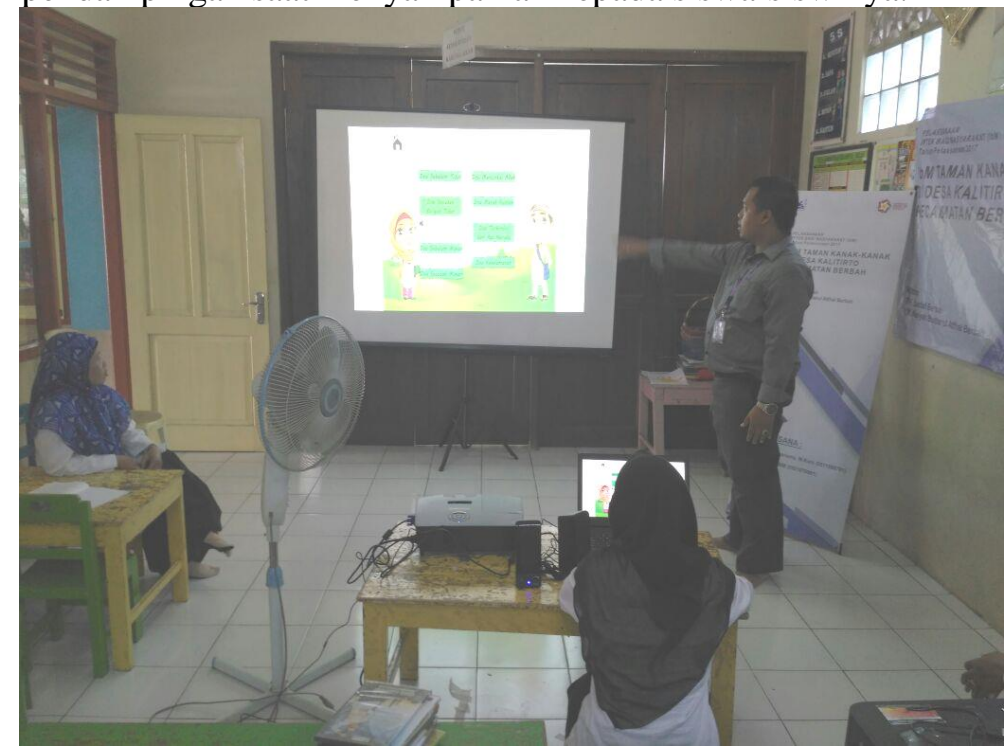

Gambar 10 Pelatihan penggunaan media pembelajaran multimedia di TK Aisiyah Bustanul Atfhal (ABA) Berbah

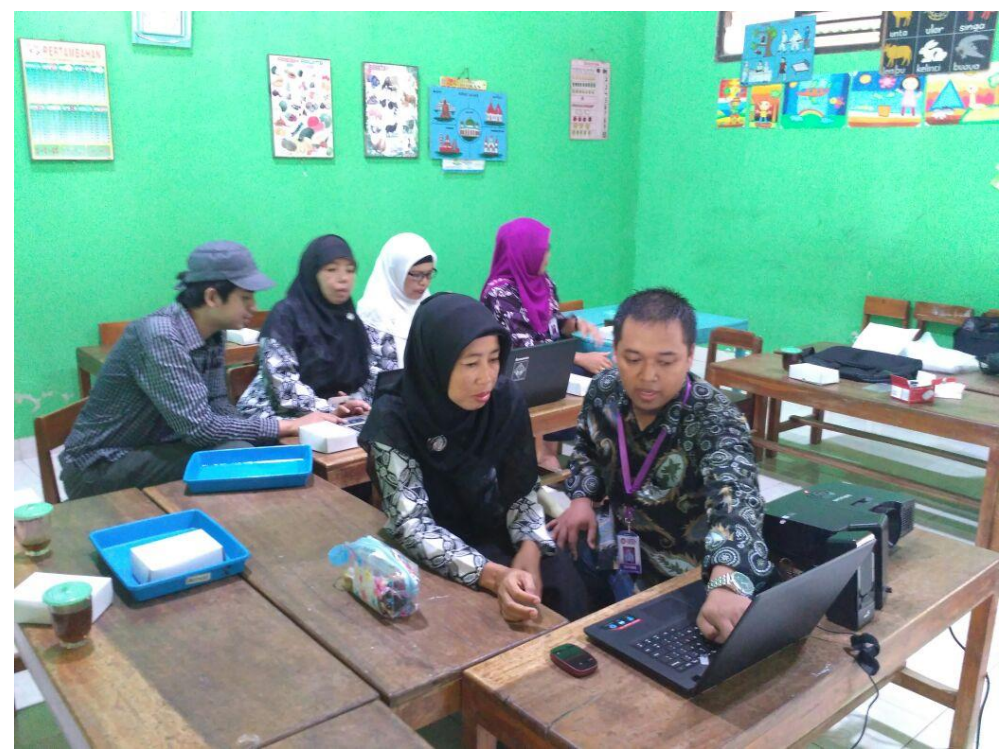

Gambar 11 Pelatihan penggunaan media pembelajaran multimedia di TK Lestari Berbah

\section{KESIMPULAN}

Dari kegitan IbM Taman Kanak-Kanak Di Desa Kalitirto Kecamatan Berbah dapat disimpulkan sebagai beriut: 1) Penggunaaan teknologi informasi dan komputer (TIK) dalam proses manajemen sekolah sangat penting dan dibutuhkan. 2) Penggunaan media pembelajaran multimedia membuat minat belajar siswa-siswi TK meningkat. 3) Penggunaan teknologi informasi dan komputer (TIK) sangat membantu Guru dan Staf TK dalam proses belajar mengajar dan proses manajemen sekolah 


\section{UCAPAN TERIMA KASIH}

Kegiatan IbM Taman Kanak-Kanak Di Desa Kalitirto Kecamatan Berbah tentunya melibatkan berbagai pihak yang mendukung baik moril maupun materiil, maka penulis mengucapkan terimakasih kepada :

1. KEMENRISTEK DIKTI, yang mengadakan program hibah Ipteks Bagi Masyarakat, sehingga kegiatan IbM Taman Kanak-Kanak Di Desa Kalitirto Kecamatan Berbah ini dapat didanai dan dilaksanakan dengan baik.

2. Universitas Amikom Yogyakarta, yang mendukung penuh kegiatan IbM Taman Kanak-Kanak Di Desa Kalitirto Kecamatan Berbah yang kami laksanakan.

3. LPM Universitas Amikom Yogyakarta, yang menugaskan kami untuk menjalankan kegiatan IbM Taman Kanak-Kanak Di Desa Kalitirto Kecamatan Berbah.

4. Dosen dan karyawan Universitas Amikom Yogyakarta yang telah berkontribusi dalam pelaksanaan IbM Taman Kanak-Kanak Di Desa Kalitirto Kecamatan Berbah.

5. TK Lestari Berbah dan TK Aisiyah Bustanul Atfhal (ABA) Berbah, yang menjadi mitra kami dalam kegiatan IbM Taman Kanak-Kanak Di Desa Kalitirto Kecamatan Berbah.

\section{DAFTAR PUSTAKA}

Sofyan, A. F., \& Purwanto, A. (2008). Digital Multimedia. Yogyakarta: ANDI.

Suyanto, M. (2003). Multimedia Alat untuk Meningkatkan Keunggulan Bersaing. Yogyakarta: ANDI.

http://disdik.slemankab.go.id/ (diakses 20 April 2016) 